\title{
The initial value problem for a tissue growth mathematical model
}

\author{
Zenggui Wang ${ }^{1}$ \\ ${ }^{1}$ Liaocheng Univ
}

July 17, 2020

\begin{abstract}
This paper considers the initial value problem for a normal hyperbolic curvature flow derived by the cell-based mathematical models of tissue growth to account for the mechanistic influence of curvature on cell evolution. The equations satisfied by support functions under this flow is a hyperbolic Monge-Amp $\$ \backslash$ grave $\{$ e $\} \$ r e$ equation. The equation for both perimeter and area of closed curves under the flow are also obtained. Based on this, we show that for a closed curve, if the initial velocity $\$ \mathrm{v}_{-}\{0\}<0 \$$, the solution of this flow converges to a point in finite time; if $\$ \mathrm{v}_{-}\{0\}>0 \$$, the solution of this flow exists for all $\$ \mathrm{t} \backslash \operatorname{in}[0, \backslash$ infty $) \$$.
\end{abstract}

\section{Hosted file}

Mauscript.pdf available at https://authorea.com/users/343855/articles/470439-the-initialvalue-problem-for-a-tissue-growth-mathematical-model

\section{Hosted file}

Mauscript . tex . tex available at https ://authorea.com/users/343855/articles/470439-the-initialvalue-problem-for-a-tissue-growth-mathematical-model 